\title{
Identification and comparative analysis of the lactoferrin and transferrin receptors among clinical isolates of gonococci
}

\author{
B. C. LEE and L. E. BRYAN
}

\begin{abstract}
Department of Microbiology and Infectious Diseases, The University of Calgary, Calgary, Alberta, Canada T2N $4 N 1$
\end{abstract}

\begin{abstract}
Summary. Neisseria gonorrhoeae expresses receptors for both lactoferrin (LF) and transferrin (TF). To determine whether qualitative or quantitative changes in these receptors, or both, correlate with the pattern of disease due to $N$. gonorrhoeae, a dot binding assay with whole cells was used to measure the absolute receptor levels expressed during iron-limited growth of strains isolated from asymptomatic patients and patients with urethritis, cervicitis, pelvic inflammatory disease and disseminated infection. Lactoferrin and transferrin receptor complexes were purified by affinity chromatography and their protein profiles were compared. The molecular weights of the LF and TF receptor complexes from a representative sample of gonococci were homogeneous. We conclude that there is no relationship between the LF and TF receptor levels and disease manifestation, auxotype or serotype.
\end{abstract}

\section{Introduction}

Iron acquisition is a microbial virulence factor (Bullen, 1981; Finklestein et al., 1983; Weinberg, 1984) but the availability of iron in the human host is limited by binding to lactoferrin (LF) and transferrin (TF), respectively present in exocrine secretions and the intravascular compartment (Bullen, 1981; Finklestein et al., 1983; Weinberg, 1984). These high-affinity iron-chelating proteins may be sources of iron for Neisseria gonorrhoeae (Micklesen and Sparling, 1981; Micklesen et al., 1982).

Certain phenotypic traits characterise gonococcal strains that cause disseminated infection. These include serum resistance, the transparent Protein II variant, the $\mathrm{AHU}^{-}$auxotype and the Protein $1 \mathrm{~A}$ serogroup (Britigan et al., 1985). In view of the importance of the ability of $N$. gonorrhoeae to capture iron from TF and LF, the question arises whether the ability of the gonococcus to utilise iron derived from these carriers is important in governing the type of disease produced. The recently described gonococcal LF and TF receptors (Lee and Schryvers, 1988) provided an opportunity to examine the hypothesis that the differential expression of these receptors might reflect differential

Received 11 May 1988; accepted 22 Aug. 1988. abilities to acquire iron from $\mathrm{LF}$ and $\mathrm{TF}$ and determine the type of clinical disease produced.

\section{Materials and methods}

\section{Bacterial strains}

A total of 40 clinical isolates of $N$. gonorrhoeae was maintained as stock cultures by freezing at $-70^{\circ} \mathrm{C}$. They were kindly provided by $\mathrm{Dr} \mathrm{R}$. C. Brunham (University of Manitoba) and were derived from a previous prospective study to correlate Protein 1 serotype and auxotype with disease expression (Brunham et al., 1985). The strains were isolated from patients with the following clinical diagnoses: Seven with asymptomatic disease, seven with urethritis, five with cervicitis, 12 with disseminated gonococcal disease, and 9 with pelvic inflammatory disease. Twenty-four of the isolates expressed the Protein 1A serotype and 16 expressed the Protein 1B serotype. Twenty-one of the strains were nutritional auxotrophs comprising five distinct auxotrophic groups.

Organisms were identified as $N$. gonorrhoeae if they had typical morphology on Gram's stain, were oxidase positive, produced acid from glucose and gave negative reactions with maltose, sucrose and $o$-nitro-phenyl- $\beta$-Dgalactoside by the Minitek method (Morse and Bartenstein, 1976). $\beta$-Lactamase production was assessed by the chromogenic cephalosporin assay (O'Callaghan et al., 1972). All isolates were $\beta$-lactamase negative.

Strains were categorised as Protein $1 \mathrm{~A}$ or $1 \mathrm{~B}$ in a coagglutination assay with a panel of monoclonal 
antibodies according to the classification system of Knapp et al. (1984). Auxotyping was performed by the method of Hendry and Stewart (1979).

\section{Lactoferrin and transferrin receptor assay}

The whole-cell assay used to identify the LF and TF receptors has been described previously (Schryvers and Morris, 1988a). Briefly, N. gonorrhoeae strains were grown overnight on heated blood agar at $37^{\circ} \mathrm{C}$ in $\mathrm{CO}_{2}$ $5 \%$ in air. Non-fimbriate cells were then inoculated into prewarmed SJ-GC broth (Shockley et al., 1980) containing $40 \mu \mathrm{M}$ desferrioxamine, a potent iron chelator, to an initial optical density of 10 Klett units, as determined with a Klett-Summerson colorimeter with a green filter (no. 540) and grown in a shaking incubator at $37^{\circ} \mathrm{C}$ in the presence of $\mathrm{CO}_{2} 5 \%$ until mid-exponential growth was achieved (60-70 Klett units). Samples of $1 \mathrm{ml}$ from these cultures were centrifuged in a Beckman microfuge and the cell pellets were resuspended in $50 \mathrm{mM}$ Tris- $\mathrm{HCl}$ buffer ( $\mathrm{pH} 7.5)$ to give a final protein concentration of $1 \mathrm{mg} / \mathrm{ml}$ as determined by the method of Lowry et al. (1951). Dots of 2- $\mu$ l volumes were applied to nitrocellulose paper ( $0.45 \mu \mathrm{m}$, Millipore Corp., Bedford, MA, USA), air dried, and blocked with skimmed milk (Johnson et al., 1984). Peroxidase-conjugated LF or TF (Jackson Immunoresearch Lab., Inc., Avondale, PA, USA) was added to the blots in skim milk and the blots were incubated for $1 \mathrm{~h}$ at $37^{\circ} \mathrm{C}$, washed and developed with chloronaphthol reagent (HRP Color Developing Reagent, Bio-Rad Lab., Richmond, CA, USA).

\section{Quantitation of lactoferrin and transferrin receptor activity}

Concentrations of TF and LF were measured with a Bio-Rad Model 620 Densitometer interfaced with an IBM PC computer incorporating the Bio-Rad I-D Analyst software package (Bio-Rad Lab.). Values obtained from individual experiments were compared with standardised controls of known concentrations of LF and TF. Equimolar concentrations of LF and TF produced equal intensities when measured.

\section{Statistical analysis}

Mean LF and TF values among the different groups were compared by a one-way analysis of variance. The difference between mean LF and TF receptor values was evaluated by the paired Student's $t$-test.

\section{Affinity-chromatography of membranes for lactoferrin and transferrin receptor}

Total membranes were prepared by the method of Schryvers and Morris (1988a) from cells grown in ironrich (SJ-GC broth alone) and iron-limited (SJ-GC broth with the addition of $40 \mu \mathrm{M}$ desferrioxamine) conditions. These preparations were enriched for $\mathrm{LF}$ and $\mathrm{TF}$ receptor by affinity chromatography with streptavidin-sepharose bound with its respective ligands (Schryvers and Morris, $1988 b$ ). The proteins were separated by sodium dodecyl sulphate (SDS-PAGE) (Laemmli and Favre, 1973) and the resultant bands stained with silver (Oakley et al., 1980).

\section{Growth experiments}

For the growth experiments, organisms were streaked onto heated blood agar from stock cultures that were frozen at $-70^{\circ} \mathrm{C}$ and the plates were incubated for 12 $14 \mathrm{~h}$ at $37^{\circ} \mathrm{C}$ in $\mathrm{CO}_{2} 5 \%$ in air. Cells were then suspended in SJ-GC broth containing $50 \mu \mathrm{M}$ desferrioxamine to an initial optical density of 10 Klett units. Cultures were shaken at $37^{\circ} \mathrm{C}$ in an atmosphere containing $\mathrm{CO}_{2} 5 \%$ until mid-exponential growth was achieved (60-70 Klett units). Samples were removed and used to inoculate fresh prewarmed SJ-GC broth containing $50 \mu \mathrm{M}$ desferrioxamine to which were added the various iron sources. Human LF and TF purified by high performance liquid chromatography were added to a final concentration of $1.25 \mu \mathrm{M}$ available iron. Ferric chloride was used at a final concentration of $50 \mu \mathrm{M}$. Growth was monitored hourly for $8 \mathrm{~h}$ with a Klett-Summerson colorimeter.

\section{Results}

LF and TF receptor values of gonococci isolated from each of the five disease categories and for each of the six different auxotypes are shown in the table. All gonococci expressed detectable levels of both LF and TF receptor, irrespective of auxotype, disease manifestation, or Protein 1 serotype (data not shown). Mean values for the $T F$ receptor exceeded those for the LF receptor in each of the five disease categories $(p<0.01)$ and in each of the seven auxotypes $(p<0.01)$. There were no significant associations between the LF and TF receptor values and disease manifestation, auxotype, or Protein 1 serotype (data not shown).

To determine whether a putative relationship may have been obscured by confounding distributional effects, such as arbitrary clinical assignment, the disease data were segregated into two classifications-localised (urethritis and cervicitis combined) and disseminated. Similarly, the $\mathrm{OHU}^{-}$ auxotype was used as a surrogate marker for dissemination (Knapp and Holmes, 1975) and these strains were compared with non-OHU ${ }^{-}$bearing strains. These manipulations did not accentuate or reveal any differences as the comparative analyses yielded results identical to the original unadjusted analysis.

Two other observations, which did not achieve statistical significance because of their small sample size, are intriguing. Unexpectedly, cervicitis strains 
Table. Lactoferrin and transferrin receptor values of $N$. gonorrhoeae strains isolated from patients with asymptomatic disease, urethritis, cervicitis, disseminated gonococcal infection and pelvic inflammatory disease

\begin{tabular}{|c|c|c|c|c|c|c|c|c|c|c|c|c|c|c|c|c|c|c|c|}
\hline \multirow{3}{*}{\multicolumn{2}{|c|}{$\begin{array}{c}\text { Auxotype Number } \\
\text { of } \\
\text { isolates } \\
\text { (n) }\end{array}$}} & \multicolumn{18}{|c|}{ Mean receptor value* (and SD) in strains from } \\
\hline & & \multicolumn{3}{|c|}{$\begin{array}{l}\text { asymptomatic } \\
\text { carriers }\end{array}$} & \multicolumn{3}{|c|}{ urethritis } & \multicolumn{3}{|c|}{ cervicitis } & \multicolumn{3}{|c|}{$\begin{array}{l}\text { disseminated } \\
\text { infection }\end{array}$} & \multicolumn{3}{|c|}{$\begin{array}{c}\text { pelvic } \\
\text { inflammatory } \\
\text { disease }\end{array}$} & \multicolumn{3}{|c|}{ all } \\
\hline & & $n$ & LF & $\mathrm{TF}$ & $\mathrm{n}$ & LF & TF & $\mathbf{n}$ & LF & TF & $\mathrm{n}$ & LF & TF & $\mathrm{n}$ & LF & TF & $\mathrm{n}$ & LF & TF \\
\hline Proto & 19 & 1 & $1 \cdot 205$ & $2 \cdot 127$ & 3 & $0 \cdot 872$ & $0 \cdot 910$ & 2 & 0.967 & $2 \cdot 646$ & 9 & $0 \cdot 816$ & $1 \cdot 343$ & 4 & $0 \cdot 960$ & $1 \cdot 651$ & 19 & $\begin{array}{c}0.929 \\
(0.395)\end{array}$ & $\begin{array}{c}1.455 \\
(0.491)\end{array}$ \\
\hline $\mathrm{PCU}^{-}$ & 8 & 1 & $1 \cdot 396$ & $1 \cdot 270$ & 2 & $0 \cdot 801$ & 1.089 & 2 & $1 \cdot 276$ & $1 \cdot 729$ & 0 & - & $\ldots$ & 3 & 0.947 & $1 \cdot 243$ & 8 & $\begin{array}{c}1.050 \\
(0.420)\end{array}$ & $\begin{array}{c}1.330 \\
(0.597)\end{array}$ \\
\hline $\mathrm{Pro}^{-}$ & 3 & 2 & 0.914 & $2 \cdot 036$ & 1 & 0.935 & $2 \cdot 067$ & 0 & $\ldots$ & . & 0 & $\ldots$ & $\ldots$ & 0 & $\ldots$ & $\ldots$ & 3 & $\begin{array}{c}0.921 \\
(0.262)\end{array}$ & $\begin{array}{c}1.673 \\
(0.630)\end{array}$ \\
\hline $\mathrm{OHU}^{-}$ & 5 & 2 & 0.614 & $1 \cdot 275$ & 1 & $0 \cdot 177$ & 0.423 & 1 & $0 \cdot 234$ & 0.685 & 0 & $\ldots$ & . & 1 & $0 \cdot 298$ & $1 \cdot 139$ & 5 & $\begin{array}{c}0 \cdot 398 \\
(0 \cdot 265)\end{array}$ & $\begin{array}{c}0.960 \\
(0 \cdot 388)\end{array}$ \\
\hline Orn $^{-}$ & 4 & 1 & 0.900 & 0.988 & 0 & $\ldots$ & $\ldots$ & 0 & $\ldots$ & $\ldots$ & 3 & $1 \cdot 269$ & $2 \cdot 100$ & 0 & $\ldots$ & $\ldots$ & 4 & $\begin{array}{c}1 \cdot 196 \\
(0 \cdot 248)\end{array}$ & $\begin{array}{c}1.823 \\
(0.640)\end{array}$ \\
\hline $\mathrm{CU}^{-}$ & 1 & 0 & & & 0 & & & 0 & $\cdots$ & & 0 & & & 1 & 0.985 & $1 \cdot 714$ & 1 & 0.985 & 1.714 \\
\hline All & 40 & 7 & $\begin{array}{c}0.944 \\
(0.335)\end{array}$ & $\begin{array}{c}1.573 \\
(0.476)\end{array}$ & 7 & $\begin{array}{c}0.763 \\
(0.413)\end{array}$ & $\begin{array}{c}1.057 \\
(0.630)\end{array}$ & 5 & $\begin{array}{c}0.944 \\
(0.575)\end{array}$ & $\begin{array}{c}1.647 \\
(0.719)\end{array}$ & 12 & $\begin{array}{c}0.929 \\
(0.405)\end{array}$ & $\begin{array}{c}1 \cdot 532 \\
(0 \cdot 486)\end{array}$ & 9 & $\begin{array}{c}0.964 \\
(0.419)\end{array}$ & $\begin{array}{l}1.465 \\
0.477\end{array}$ & 40 & & \\
\hline
\end{tabular}

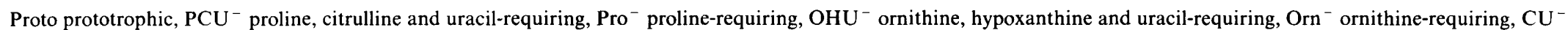
citrulline and uracil-requiring.

* Mean ng of conjugate $/ \mu \mathrm{g}$ wet weight total cell protein. 
possessed the highest TF receptor values. Paradoxically, the $\mathrm{OHU}^{-}$auxotype displayed the lowest LF and TF receptor levels among the auxotypes scrutinised.

An examination of the silver-stained SDS-PAGE preparation (figs. 1 and 2) disclosed no major differences between the protein profiles of the LF and the TF receptor complexes among a representative selection of isolates from localised and disseminated gonococcal infection. A prominent 101-Kda protein, the putative LF receptor, was present in all the LF receptor affinity-enriched ironlimited preparations (arrow, fig. 1, lanes $\mathrm{d}-\mathrm{g}$ ). This band was absent from both the control sample grown in iron-rich conditions (fig. 1, lane b), indicating the iron-regulated nature of the protein, and from the samples processed for the $T F$ receptor (fig. 2, lanes $\mathrm{d}-\mathrm{g}$ ), thus demonstrating the ligand specificity of the affinity chromatography method.

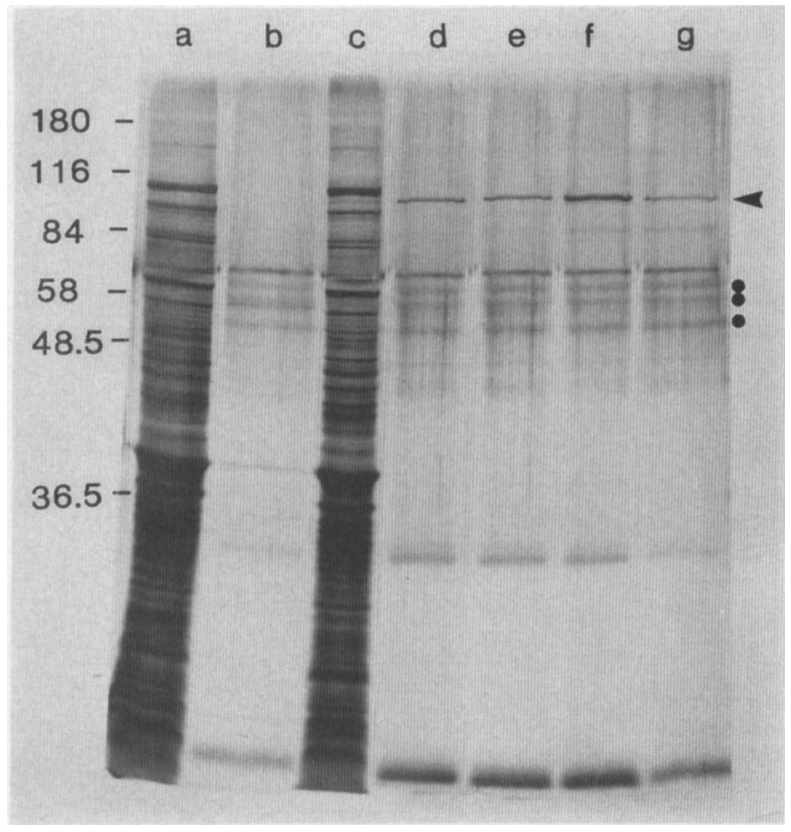

Fig. 1. SDS-PAGE of crude total membranes showing lactoferrin-receptor complexes of five clinical isolates of gonococci. The protein profiles are shown in lanes $d-g$, where lane $d$ is W003 and lane e W006 (both strains from disseminated infections), lane f W202 (a urethritis strain), and lane g W159 (a cervicitis strain). For comparison, lanes a and $\mathrm{c}$ represent the starting crude total membranes of strain W003 cultured in iron-rich and iron-limited SJ-GC broth respectively. Lane b is the corresponding affinity-enriched sample prepared from the starting material in lane a. Strains W003, W006 and W202 expressed the Protein lA serotype whereas strain W159 expressed the Protein 1B serotype. All the strains were prototrophic auxotrophs. Molecular weight markers $(\mathrm{Kda})$ are displayed on the left side of the gel. Arrows $(4)$ designate the protein bands representing the putative lactoferrin receptor. Dots $(\bullet)$ indicate contaminating bands present in the polyacrylamide gel matrix.

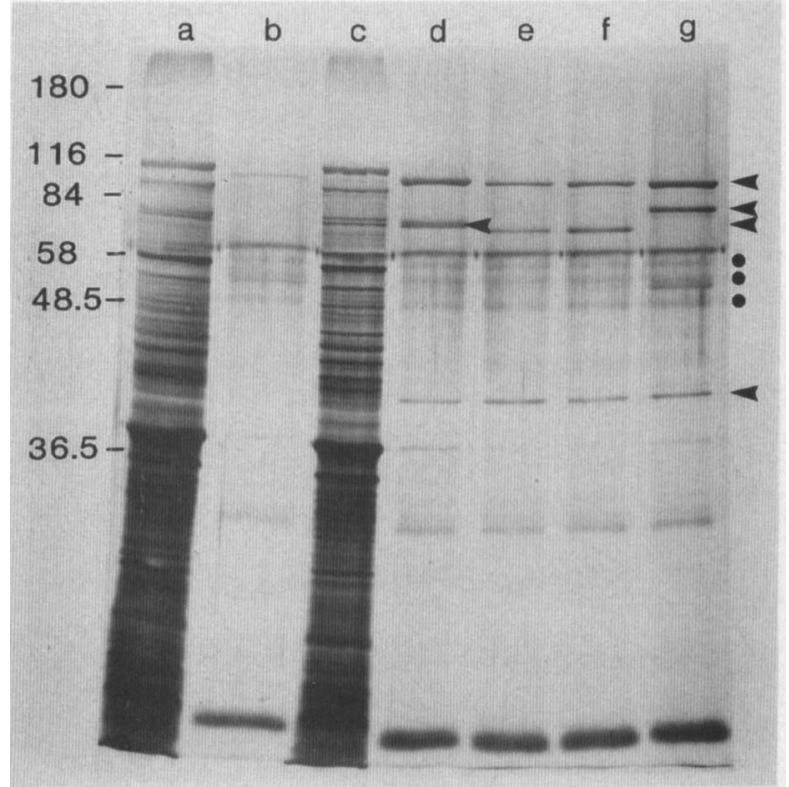

Fig. 2. SDS-PAGE of crude total membranes showing transferrin receptor complexes of five clinical isolates of gonococci. The protein profiles are shown in lanes $\mathrm{d}-\mathrm{g}$, where lane $\mathrm{d}$ is W003 and lane e W006 (both strains from disseminated infections), lane f W202 (a urethritis strain), and lane g W159 (a cervicitis strain). For comparison, lanes a and $\mathrm{c}$ represent the starting crude total membranes of strain W003 cultures in iron-rich and iron-limited SJ-GC broth respectively. Lane b is the corresponding affinity-enriched sample prepared from the starting material in lane a. Strains W003, W006, and W202 expressed the Protein 1A serotype whereas strain W159 expressed the Protein 1B serotype. All the strains were prototrophic auxotrophs. Molecular weight markers (Kda) are displayed on the left side of the gel. Arrows $(4)$ designate the protein bands representing the putative transferrin receptor. Dots $(\bullet)$ indicate contaminating bands present in the polyacrylamide gel matrix.

Similarly, five bands of $98,74 \cdot 5,68 \cdot 5,66 \cdot 5$, and $37 \mathrm{Kda}$ were either co-purified or enhanced in the iron-limited samples subjected to the TF-receptor affinity chromatography protocol (arrows, fig. 2, lanes $\mathrm{d}-\mathrm{g}$ ) when compared with the iron-rich control membrane sample (fig. 2, lane b) and the samples prepared for the LF receptor (fig. 1, lanes $d-g$ ). Other polypeptide bands that were present were common to both the affinity purified iron-rich and iron-limited preparations and represent contaminating fractions present in the acrylamide gel matrix (dots, figs. 1 and 2) or proteins binding nonspecifically to the affinity gel. The latter proteins can be preferentially eluted with stringent washing conditions, without disturbing the appearance of the enhanced bands (data not shown).

Functional differences were not identified in the ability of iron-limited cultures of isolates from urethritis and disseminated gonococcal infection to 
utilise either LF or TF as the sole exogenous source (data not shown).

Attempts to identify either the LF or the TF receptor by a binding assay after SDS-PAGE and electroblotting (Schryvers and Morris, 1988b) failed, indicating that the LF and TF receptor binding sites are conformationally dependent (data not shown).

\section{Discussion}

This survey of LF and TF receptor expression in clinical isolates of gonococci did not support the concept that qualitative or quantitative differences in the TF receptor alone can predict intravascular invasion. Analysis of the TF-receptor values, functional status, or molecular weight failed to discriminate between strains from localised and disseminated gonococcal infection. This can be explained because it is understood that the process of bacterial virulence is complex and involves, sequentially or in concert, an array of bacterial virulence determinants (Sparling, 1983). In this context, the interaction of Protein II and serum resistance, two other phenotypic traits epidemiologically linked to strains from disseminated gonococcal infection (Britigan et al., 1985), with TFreceptor levels may prove instructive.

However, despite the lack of an association, two tantalising observations emerge from this investigation. Firstly, the low expression of LF receptor in the $\mathrm{OHU}^{-}$strains may be the molecular correlate of the recognised inability of such auxotypes to acquire iron from LF (Micklesen et al., 1982) and may account, in part, for the frequent association of this auxotype with asymptomatic gonorrhoea (Knapp and Holmes, 1975). Additional explanations, such as qualitative differences in the LF receptor or differences in processing of the ligandreceptor complex cannot be excluded.

Finally, the LF and TF receptor complexes enriched by affinity-chromatography correspond

\section{REFERENCES}

Brunham R C, Plummer F, Slaney L, Rand F, DeWitt W 1985 Correlation of auxotype and Protein I type with expression of disease due to Neisseria gonorrhoeae. Journal of Infectious Diseases 152: 339-343.

Britigan B E, Cohen M S, Sparling P F 1985 Gonococcal infection : a model of molecular pathogenesis. New England Journal of Medicine 312: 1683-1694.

Bullen J J 1981 The significance of iron in infection. Reviews of Infectious Diseases 3: 1127-1138. with iron-regulated gonococcal proteins of similar molecular weight previously described (West and Sparling, 1985; Meitzner et al., 1986). The enhancement of a $101-\mathrm{Kda}$ protein band by LF affinitychromatography identifies this protein as the putative LF receptor. In contrast, several bands were co-purified by the TF process. Two of these proteins of 98 and $37 \mathrm{Kda}$ were represented in all the gonococcal strains examined, whereas the third co-purified protein exhibited interstrain molecular weight heterogeneity, varying from 66.5 to $74.5 \mathrm{Kda}$. This suggests that the $T F$ receptor consists of a functional complex of three proteins. One of these, a $37-\mathrm{Kda}$ protein, may correspond with a previously shown iron-regulated protein that is antigenically conserved among pathogenic Neisseria spp. (Meitzner et al., 1986). The co-elution of this protein as a component of the TF-receptor complex tentatively supports the contention that it is involved in iron uptake (Meitzner et al., 1986). Alternatively, the use of more stringent methods of affinity purification might have permitted the definitive assignment of the TF receptor to a single protein band. The possibility that these bands represent degradation products of the TF receptor cannot be excluded. The relative molecular weight homogeneity of all these binding proteins suggests a functional conservation, consistent with their important role in iron acquisition. Implicit also from these results is the existence of separate receptors for LF and TF. Their uniform presence in iron-limited conditions suggests coordinate expression.

Thus, the exact contributions of these receptors in governing diseases expression remain to be elucidated. Since ability to acquire iron is a trait critical to virulence, it is to be expected that their roles will be significant.

We thank G. Fick and Heather Bryant for help with the statistical analysis. This study was supported by an Alberta Heritage Foundation for Medical Research Clinical Fellowship to B.C.L.
Finkelstein R A, Sciortino C V, McIntosh M A 1983 Role of iron in microbe-host interactions. Reviews of Infectious Diseases 5 Suppl 4: 759-777.

Hendry A T, Stewart I O 1979 Auxanotrophic grouping and typing of Neisseria gonorrhoeae. Canadian Journal of Microbiology 25 : 512-521.

Johnson D A, Gautsch J W, Sportsman J R, Elder J H 1984 Improved technique utilising nonfat dry milk for analysis of proteins and nucleic acids transferred to nitrocellulose. Gene Analysis Techniques 1 : 3-8.

Knapp J S, Holmes K K 1975 Disseminated gonococcal 
infections caused by Neisseria gonorrhoeae with unique nutritional requirements. Journal of Infectious Diseases 132: 204-208.

Knapp J S, Tam M R, Nowinski R C, Holmes K K, Sandstrom E G 1984 Serological classification of Neisseria gonorrhoeae with the use of monoclonal antibodies to gonococcal outer membrane protein. Journal of Infectious Diseases 150: 4448.

Laemmli U K, Favre M 1973 Maturation of the head of bacteriophage T4. I. DNA packaging events. Journal of Molecular Biology 80 : 575-599.

Lee B C, Schryvers A B 1988 Specificity of the lactoferrin and transferrin receptors in Neisseria gonorrhoeae. Molecular Microbiology 2: 827-833.

Lowry O H, Rosebrough N J, Farr A L, Randall R J 1951 Protein measurement with the folin phenol reagent. Journal of Biological Chemistry 193: 265-275.

Mietzner T A, Barnes R C, Jean Louis Y A, Shafer W M, Morse S A 1986 Distribution of an antigenically related ironregulated protein among the Neisseria spp. Infection and Immunity 51 : 60-68.

Mickelsen P A, Blackman E, Sparling P F 1982 Ability of Neisseriagonorrhoeae, Neisseria meningitidis, and commensal Neisseria species to obtain iron from lactoferrin. Infection and Immunity 35: 915-920.

Mickelsen P A, Sparling P F 1981 Ability of Neisseria gonorrhoeae, Neisseria meningitidis, and commensal Neisseria species to obtain iron from transferrin and iron compounds. Infection and Immunity 33: 555-564.
Morse S A, Bartenstein L 1976 Adaption of the Minitek system for the rapid identification of Neisseria gonorrhoeae. Journal of Clinical Microbiology 3: 8-13.

Oakley B R, Kirsch D R, Morris N R 1980 A simplified ultrasensitive silver stain for detecting proteins in polyacrylamide gels. Analytical Biochemistry 105: 361-363.

O'Callaghan C H, Morris A, Kirby S M, Shingler A H 1972 Novel method for detection of beta-lactamases by using a chromogenic cephalosporin substrate. Antimicrobial Agents and Chemotherapy $1: 283-288$.

Schryvers A B, Morris L J $1988 a$ Identification and characterisation of the transferrin receptor from Neisseria meningitidis. Molecular Microbiology 2: 281-288.

Schryvers A B, Morris L J $1988 b$ Identification and characterisation of the human lactoferrin-binding protein from Neisseria meningitidis. Infection and Immunity 56: 114-119.

Shockley R K, Coffee E E, Johnston K H 1980 SJ-GC, a modified complete medium for the growth of Neisseria gonorrhoeae. Journal of Clinical Microbiology 12: 35-38.

Sparling P F 1983 Bacterial virulence and pathogenesis: an overview. Reviews of Infectious Diseases 5 Suppl 4: 637-646.

Weinberg E D 1984 Iron withholding: a defense against infection and neoplasia. Physiological Reviews 64: 65-102.

West S E, Sparling P F 1985 Response of Neisseria gonorrhoeae to iron limitation: alterations in expression of membrane proteins without apparent siderophore production. Infection and Immunity 47: 388-394. 